\title{
PENGARUH PENERAPAN ENTERPRISE RESOURCES PLANNING TERHADAP KINERJA KEUANGAN PERUSAHAAN CONSUMER GOOD DI BURSA EFEK INDONESIA
}

\author{
Oleh: \\ Dwi Rorin Mauludin Insana ${ }^{1}$ \\ Eko Cahyo Mayndarto ${ }^{2}$
}

${ }^{1}$ Program Studi Pendidikan Bahasa Inggris, Fakultas Bahasa dan Seni
Universitas Indraprasta PGRI Jakarta
${ }^{2}$ Program Studi Akuntansi, Fakultas Ekonomi
Universitas Tama Jagakarsa

Email:

dwirorin@gmail.com

\begin{abstract}
Enterprise Resources Planning systems are expected to: (1) reduce costs by increasing efficiency through computerization; (2) improve decision making by providing accurate and timely company-wide information; (3) better communication with customers and suppliers, and (4) better control over the business. The purpose of this study was to determine the effect of ERP system implementation on the company's financial performance. Analysis carried out on this company by comparing the first, second and third quartile before and after ERP implementation in the indication of inventory turnover ratio, weeks of supply, net profit margin, gross profit margin, operating profit margin. Based on the results of calculations using SPSS version 13.00 and data analysis performed on 33 consumer good companies listed on the Indonesian stock exchange by comparing before and after the ERP launch to the financial performance index reviewed from inventory ratio turnover indicators, weeks of supply, net profit margin, gross profit margin, operating margin and pretax margin and cash flow ratio, it can be concluded that there are significant differences between the company's financial performance before and after the launch of ERP. The company's financial performance increases after using ERP. This indicates the effectiveness and efficiency of the company in managing financial resources after using ERP. Thus this result is expected to be able to increase the competitiveness of companies in the future.
\end{abstract}

Keywords: Enterprise Resources Planning, Financial Performance 


\begin{abstract}
ABSTRAK
Sistem Enterprise Resources Planning (ERP) diharapkan untuk: (1) mengurangi biaya dengan meningkatkan efisiensi melalui komputerisasi; (2) meningkatkan pengambilan keputusan dengan menyediakan informasi yang akurat dan tepat waktu perusahaan-lebar; (3) komunikasi yang lebih baik dengan pelanggan dan pemasok, dan (4) Pengendalian yang lebih baik alih bisnis. Tujuan penelitian ini untuk mengetahui pengaruh penerapan sistem ERP terhadap kinerja keuangan perusahaan. Analisa yang dilakukan pada perusahaan ini dengan membandingkan nilai kuartil pertama, kedua dan ketiga sebelum dan sesudah implementasi ERP pada indeks fianancial performance yang ditelaah dari indikator turnover inventory ratio, weeks of supply, net profit margin, gross profit margin, operating margin and pretax margin dan cash flow ratio. Berdasarkan hasil perhitungan dengan menggunakan SPSS version 13.00 dan analisa data yang dilakukan pada 33 perusahaan consumer good yang terdaftar pada bursa efek Indonesia dengan membandingkan sebelum dan sesudah launching ERP terhadap indeks fianancial performance yang ditelaah dari indikator turnover inventory ratio, weeks of supply, net profit margin, gross profit margin, operating margin and pretax margin dan cash flow ratio dapat disimpulkan bahwa terdapat perbedaan yang signifikan antara kinerja keuangan perusahaan sebelum dan sesudah launching ERP. Kinerja keuangan perusahaan meningkat setelah menggunakan ERP. Hal ini mengindikasikan adanya efektifitas dan efisiensi perusahaan dalam mengelola sumberdaya keuangan setelah menggunakan ERP. Dengan demikian hasil ini diharapkan mampu meningkatkan daya saing perusahaan di masa yang akan datang.
\end{abstract}

Kata Kunci : Enterprise Resources Planning, Kinerja keuangan

\title{
A. PENDAHULUAN
}

Implementasi Enterprise Resources Planning (ERP) pada perusahaan di Indonesia mempunyai harapan untuk mempercepat proses bisnis, meningkatkan efisiensi, dan meraup pendapatan yang lebih besar. Persoalannya pada saat implementasi terdapat banyak faktor yang dapat menggagalkan proses tersebut. Faktor-faktor ini merupakan masalah yang dihadapi antara lain; pertama, manajemen tidak menyediakan proyek tim yang terbaik pada proyek implementasi menyangkut kompetensi anggota tim, kredibilitas dan kreativitas tim proyek, kepemimpinan tim yang efektif, komitmen tim, tanggung jawab tim, jumlah tim yang memadai, tanggungjawab yang tumpang tindih pada tim, pendekatan kerja yang kurang jelas, tujuan yang tidak dipahami oleh tim proyek (Warta Ekonomi, 2002). Penelitian Bradford \& Florin (2003) menunjukkan bahwa komitmen para manajemen puncak mendukung tim implementasi ERP khususnya manajer fungsi (key user) dan pengguna memberi peningkatan efektifitas kerja secara signifikan. Dukungan kerja yang diberikan para manajemen puncak berupa penjelasan visi dan misi perusahaan yang dikomunikasikan dengan baik kepada tim implementasi. 
Kedua, manajemen tidak mampu membedakan bahwa e-business bukanlah sekedar investasi teknologi informasi melainkan perbaikan proses bisnis atau peningkatan bisnis dengan didukung teknologi informasi. Hal ini berakibat pada nilai investasi e-business yang ditanamkan tak bisa kembali, karena banyak pimpinan perusahaan yang memiliki pengertian bahwa e-business adalah sekedar investasi teknologi informasi, bukan investasi bisnis yang didukung teknologi informasi. Menurut Goenawan dalam Warta Ekonomi (2002) banyak perusahaan di Indonesia yang melakukan investasi teknologi informasi sebesar 1\% - 2\% dari pendapatannya, dan kebanyakan investasinya tidak mampu kembali. Sedangkan masalah ketiga sebagaimana dikemukakan Goenawan adalah manajemen kurang memahami proses implementasi e-business yang benar, manajemen tidak memberikan dukungan efektif terhadap implementasi e-business di perusahaannya sendiri.

Kesuksesan implementasi ERP pada perusahaan ditentukan oleh komitmen manajemen (Yusuf et al., 2006; Umble et al., 2003; Soja, 2006; Nah et al., 2001; Aladwani, 2001; Mabert et al., 2001; Wu, 2007) yang mendukung dan memfasilitasi kebutuhan-kebutuhan yang diperlukan saat implementasi. Namun dari peneliti-peneliti sebelumnya ini masih melakukan eksplorasi terhadap komitmen manajemen puncak dalam implementasi ERP, belum ada penekanan terhadap karakteristik dari manajemen puncak. Pada penelitian ini ditekankan pada kompetensi manajemen puncak dalam menghasilkan komitmen untuk mendukung proses implementasi ERP pada perusahaan manufaktur.

Penerapan berbagai solusi elektronik bisnis yang dikenal dengan istilah ebusiness di Indonesia mulai berkembang sejak tahun 2002. Divisi keuangan merupakan bagian yang paling banyak terkait dengan aplikasi ini. Pertengahan tahun 2002 kalangan pengusaha Indonesia yakin bahwa menggunakan teknologi e-business dapat membenahi kinerja perusahaan khususnya, yang terkait dengan upaya mengefisiensikan kinerja operasional perusahaan (Warta ekonomi, 2002). Penelitian yang dilakukan oleh Warta Ekonomi memperlihatkan bahwa sekitar $54,2 \%$ perusahaan yang menjadi responden sudah menerapkan berbagai aplikasi/solusi e-business diantaranya enterprise resources planning, supply chain management dan customer relationship management. Dari riset yang sama, 31 perusahaan dari 33 perusahaan sebagai sampel $(93,9 \%)$ menyatakan bahwa departemen yang paling banyak terkait dengan aplikasi e-business adalah divisi keuangan. Posisi berikutnya ditempati masing-masing aplikasi untuk bidang pemasaran dan produksi. Hasil survey tersebut juga menyebutkan industri manufaktur tercatat paling banyak menggunakan aplikasi/solusi e-business yakni sebesar $41,9 \%$. Perusahaan tidak ragu-ragu menyebutkan bahwa pemanfaatan solusi e-business dapat meningkatkan produktivitas perusahaan. Hal ini terlihat dari hasir survey yang menyebutkan sekitar 26 dari 33 perusahaan atau 78,8\% produktivitas meningkat (Warta Ekonomi, 2002).

Program ERP sangat membantu perusahaan yang memiliki proses bisnis yang luas dengan menggunakan database dan reporting tools manajemen yang terbagi. Proses bisnis merupakan sekelompok aktivitas yang memerlukan satu atau berbagai jenis input yang akan menghasilkan output sebagai value untuk konsumen. Software ERP mendukung pengoperasian yang efisien dari proses 
bisnis dengan cara mengintegrasikan aktivitas-aktivitas dari keseluruhan bisnis termasuk sales, marketing, manufacturing, logistic, accounting, dan staffing (Leon, 2005). Sistem ERP diharapkan untuk: (1) mengurangi biaya dengan meningkatkan efisiensi melalui komputerisasi; (2) meningkatkan pengambilan keputusan dengan menyediakan informasi yang akurat dan tepat waktu perusahaan-lebar; (3) komunikasi yang lebih baik dengan pelanggan dan pemasok, dan (4) Pengendalian yang lebih baik alih bisnis. Berdasakan penjelasan di atas maka peneliti tertarik untuk melihat pengaruh penggunaan system ERP terhadap kinerja keuangan perusahaan.

\section{B. KAJIAN PUSTAKA}

Teknologi yang berperan mengintegrasikan tiap fungsi dalam perusahaan, yakni teknologi Enterprise Resources Planning (ERP). Teknologi ERP dapat mengintegrasikan fungsi marketing, fungsi produksi, fungsi logistik, fungsi finance, fungsi sumber daya manusia, dan fungsi lainnya (Baheshti, 2006). ERP telah berkembang sebagai alat integrasi, memiliki tujuan untuk mengintegrasikan semua aplikasi perusahaan ke pusat penyimpanan data dengan mudah diakses oleh semua bagian yang membutuhkan (Sabana, 2002). Menurut Leon (2005) sebagaimana juga diungkapkan oleh Genoulaz \& Millet, (2006) integrasi data pada teknologi ERP dilakukan dengan single data entry yakni sebuah departemen fungsi memasukkan data, maka data ini dapat digunakan oleh fungsi-fungsi lainnya pada perusahaan.

Enterprise Resource Planning (ERP) merupakan suatu cara untuk mengelola sumber daya perusahaan dengan menggunakan teknologi informasi (Spathis and Constantinides, 2003), yang dilengkapi dengan hardware dan software. Teknologi ini berfungsi untuk mengkoordinasi dan mengintegrasikan data informasi pada setiap area proses bisnis sehingga menghasilkan pengambilan keputusan yang cepat karena menyediakan analisa dan laporan keuangan yang cepat, laporan penjualan yang on time, laporan produksi dan inventori (Gupta, 2000). Pendapat berbeda dikemukakan Bradford \& Florin (2003) yang menyatakan bahwa tidak ada pengaruh technical compatibility technology ERP terhadap kepuasan kerja maupun efektifitas key user pada hardware dan software ERP.

Fan, et al. dalam Yusuf, et al., (2006) menyatakan ERP merupakan fungsi sistem aplikasi software yang dapat membantu organisasi dalam mengendalikan bisnis yang lebih baik karena dapat mengurangi tingkat stok dan inventori, meningkatkan perputaran stok, mengurangi cycle time order, meningkatkan produktivitas, komunikasi lebih baik serta berdampak pada peningkatan benefit (profit) perusahaan. Sedangkan Leon (2005) menyatakan bahwa ERP mempunyai keuntungan dengan pengurangan lead-time, pengiriman tepat waktu, pengurangan dalam waktu siklus, kepuasan pelanggan yang lebih baik, kinerja pemasok yang lebih baik, peningkatan fleksibilitas, pengurangan dalam biaya-biaya kualitas, penggunaan sumber daya yang lebih baik, peningkatan akurasi informasi dan kemampuan pembuatan keputusan.

Herdiawan dalam Warta Ekonomi (2006) melaporkan bahwa sistem ERP telah diterapkan pada perusahaan manufaktur makanan yang mendapatkan keuntungan yakni integrasi sistem di seluruh grup perusahaan; data informasi 
menjadi lebih lengkap, detail dan cepat; memudahkan direksi membuat analisis dan mengambil keputusan; proses usaha yang lebih sederhana; penghematan ongkos produksi; dan terakhir arus kas perusahaan yang lebih terkontrol. Berbeda dengan Herdiawan (2006), Bradford \& Florin (2003) mengemukakan bahwa businees process re-engineering tidak mempunyai pengaruh terhadap efektifitas kerja dan kepuasan key user dalam mengimplementasikan ERP di perusahaan. Penelitian yang dilakukan Zhang et al., (2005) menyatakan businees process reengineering berpengaruh positif terhadap user satisfaction dan individual impact, karena dengan mendesain kembali proses-proses pada perusahaan oleh key user akan memudahkan penyesuaian antara software dengan kebutuhan perusahaan serta berdampak pada percepatan implementasi ERP.

\section{Tabel 1}

Faktor-Faktor Sukses Implementasi ERP

\begin{tabular}{|c|c|c|c|c|c|c|c|c|c|c|}
\hline \multicolumn{2}{|c|}{ Variabel } & $\begin{array}{l}\text { Sun, } \\
\text { et al. } \\
2005\end{array}$ & $\begin{array}{l}\text { Yusuf, } \\
\text { et al. } \\
2006\end{array}$ & $\begin{array}{l}\text { Umble } \\
\text {, et al. } \\
2003\end{array}$ & $\begin{array}{l}\text { Hong, } \\
\text { Kim, } \\
2002\end{array}$ & $\begin{array}{l}\text { Zang, } \\
\text { et al. } \\
2005\end{array}$ & $\begin{array}{l}\text { Masha } \\
\text {-ri } \\
2003\end{array}$ & $\begin{array}{l}\text { Wu } \\
\& \text { Wan } \\
\text { g, } \\
2007\end{array}$ & $\begin{array}{l}\text { Soja, } \\
2006\end{array}$ & $\begin{array}{c}\text { Kumar, } \\
\text { et al., } \\
2003\end{array}$ \\
\hline 1 & $\begin{array}{l}\text { Komitmen } \\
\text { Manajemen Puncak }\end{array}$ & - & $\checkmark$ & $\checkmark$ & & & & & $\checkmark$ & \\
\hline 2 & Biaya \& Waktu & $\checkmark$ & $\checkmark$ & & & & & & $\checkmark$ & \\
\hline 3 & Budaya Organisasi & & $\checkmark$ & & $\checkmark$ & $\checkmark$ & $\checkmark$ & & & $\checkmark$ \\
\hline 4 & Jadwal \& Tujuan & $\checkmark$ & & $\checkmark$ & & & & & & $\checkmark$ \\
\hline 5 & Faktor Teknis & & $\checkmark$ & & & & & & & \\
\hline 6 & $\begin{array}{l}\text { Tenaga Ahli (Vendor } \\
\text { \& Konsultan) }\end{array}$ & & $\checkmark$ & & & $\checkmark$ & & & & \\
\hline 7 & Prasarana Perusahaan & & $\checkmark$ & & & & & & & $\checkmark$ \\
\hline 8 & $\begin{array}{l}\text { Kemampuan } \\
\text { Manajemen Puncak }\end{array}$ & & & $\checkmark$ & & & & & $\checkmark$ & \\
\hline 9 & $\begin{array}{l}\text { Kemampuan Tim } \\
\text { Proyek }\end{array}$ & & & $\checkmark$ & & $\checkmark$ & & & $\checkmark$ & $\checkmark$ \\
\hline 10 & Key User & & & & & & & $\checkmark$ & & \\
\hline 11 & $\begin{array}{l}\text { Product Data } \\
\text { Management }\end{array}$ & & & $\checkmark$ & $\checkmark$ & & & & $\checkmark$ & \\
\hline 12 & Pengukuran Kinerja & & & $\checkmark$ & & & $\checkmark$ & & & \\
\hline 13 & Bisnis Proses & & & & $\checkmark$ & $\checkmark$ & $\checkmark$ & & & $\checkmark$ \\
\hline 14 & Pengguna (End user) & & & & $\checkmark$ & $\checkmark$ & $\checkmark$ & & & \\
\hline 15 & Konsultan \& Vendor & & & & & $\checkmark$ & & $\checkmark$ & & \\
\hline 16 & Strength Product ERP & & & & & $\checkmark$ & $\checkmark$ & $\checkmark$ & $\checkmark$ & $\checkmark$ \\
\hline 17 & $\begin{array}{l}\text { Pelatihan \& } \\
\text { Pendidikan }\end{array}$ & & & $\checkmark$ & & & $\checkmark$ & $\checkmark$ & & $\checkmark$ \\
\hline 18 & Keuangan Perusahaan & & & & & & & & $\checkmark$ & \\
\hline 19 & Sistem & & & & & $\checkmark$ & & & $\checkmark$ & $\checkmark$ \\
\hline
\end{tabular}

Penelitian terhadap faktor keuangan enterprise resources planning masih relatif sedikit, dan berdasarkan pada Tabel 1, baru didapatkan satu peneliti yang membahas dari persefektif keuangan perusahaan. Anggaran dari sisi keuangan perusahaan merupakan salah satu faktor yang menentukan keberhasilan dalam implementasi teknologi enterprise resources planning (Soja, 2006). Penelitian ini 
merupakan pengembangan dari penelitian Wier et al., (2007) yang menyarankan untuk membahas dari sisi financial performance. Wier et al., (2007) menyatakan bahwa kinerja perusahaan merupakan gabungan dari enterprise resources planning implementation, non-financial performance, financial performance and control variables. Rekasi pasar terhadap perusahaan yang mengimplementasikan ERP menurut Lakonishok and Vermaelen (1995) bahwa implementasi ERP akan memberikan benefit pada harga saham dan implikasi lainnya bagi perusahaan.

Berdasarkan kajian pustaka di atas maka penelitia memiliki kerangka pemikiran dalam penelitian ini yaitu ingin mengetahui kinerja keuangan perusahaan melalui faktor-faktor; ratio inventory turnover, Weeks of Supply, net profit margin, gross profit margin, operating margin, pretax margin, cash flow to liabilities, cash flow to sales revenue dan cash flow to total assets sebelum penggunaan sistem ERP dibandingkan setelah penggunaan sistem ERP.

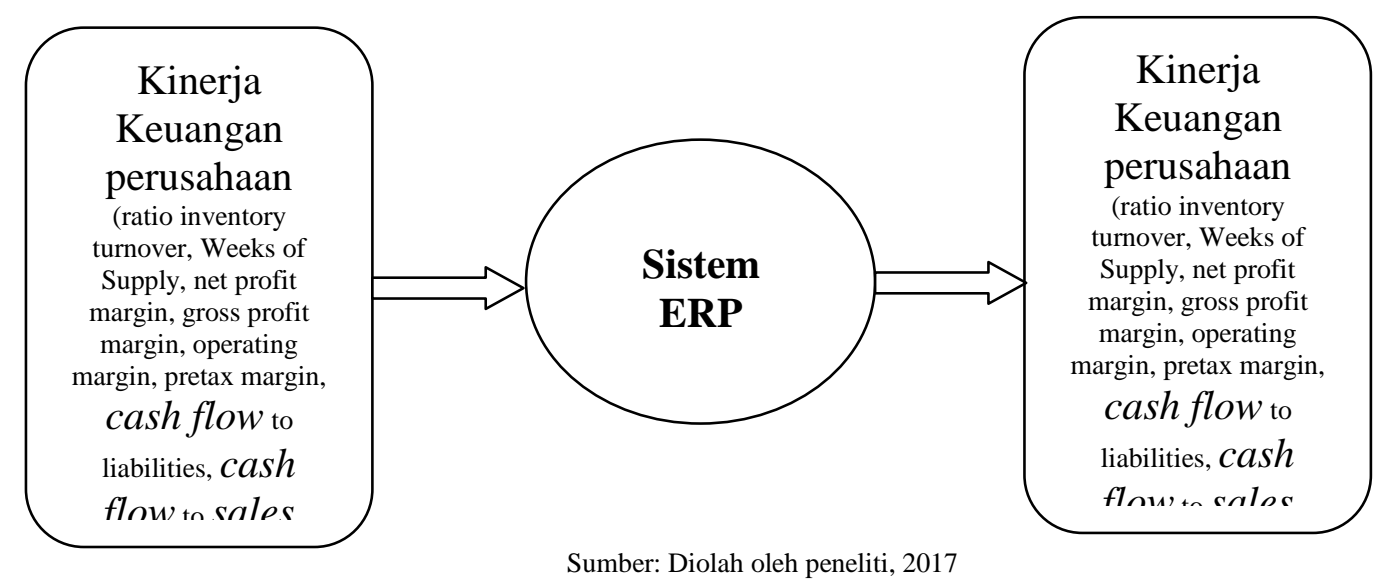

Gambar 1.

Kerangka Pemikiran

Adapun hipotesis pada penelitian ini dapat dirumuskan sebaga berikut:

$\mathrm{H}_{1}$ : Terdapat pebedaan yang signifikan penggunaan ERP terhadap kinerja keuangan perusahaan melalui faktor ratio inventory turnover.

$\mathrm{H}_{2}$ : Terdapat pebedaan yang signifikan penggunaan ERP terhadap kinerja keuangan perusahaan melalui faktor Weeks of Supply.

$\mathrm{H}_{3}$ : Terdapat pebedaan yang signifikan penggunaan ERP terhadap kinerja keuangan perusahaan melalui faktor Net profit margin.

$\mathrm{H}_{4}$ : Terdapat pebedaan yang signifikan penggunaan ERP terhadap kinerja keuangan perusahaan melalui faktor gross profit margin.

$\mathrm{H}_{5}$ : Terdapat pebedaan yang signifikan penggunaan ERP terhadap kinerja keuangan perusahaan melalui faktor Operating Margin.

$\mathrm{H}_{6}$ : Terdapat pebedaan yang signifikan penggunaan ERP terhadap kinerja keuangan perusahaan melalui faktor Pretax margin.

$\mathrm{H}_{7}$ : Terdapat pebedaan yang signifikan penggunaan ERP terhadap kinerja keuangan perusahaan melalui faktor $C F O$ to Liabilities. 
$\mathrm{H}_{8}$ : Terdapat pebedaan yang signifikan penggunaan ERP terhadap kinerja keuangan perusahaan melalui faktor $C F O$ to Sales revenue.

$\mathrm{H}_{9}$ : Terdapat pebedaan yang signifikan penggunaan ERP terhadap kinerja keuangan perusahaan melalui faktor $C F O$ to total assets.

\section{METODE PENELITIAN}

Penelitian ini merupakan penelitian kuantitatif dengan metode studi kasus yang menjelaskan secara deskriptif variabel-variabel yang ada di dalamnya (Sugiyono, 2015). Penelitian ini dilakukan dengan mengamati dan menganalisa tentang pengaruh penggunaan sistem ERP terhadap kinerja keuangan pada perusahaan-perusahaan yang masuk pada bursa efek Indonesia khususnya jenis manufaktur consumer good. Teknik pengambilan sampel dilakukan dengan purposive sampling, yaitu teknik penentuan sampel dengan pertimbangan tertentu (Sugiyono, 2015). Sedangkan menurut Sukardi (2011) bahwa dalam teknik purposive sampling menentukan seseorang menjadi sampel atau tidak didasarkan pada tujuan tertentu. Penentuan sampel dalam penelitian ini ditentukan berdasarkan kriteria yaitu perusahaan-perusahaan yang terdaftar di bursa efek Indonesia berdasarkan homogenitas elemen segmen yang sama yakni consumer good (data tahun 2010-2013). Jumlah perusahaan consumer good yang terdapat pada bursa efek Indonesia sebanyak 35 perusahaan yang terdiri atas 15 perusahaan bergerak di bidang makanan dan minuman, 9 perusahaan bergerak di bidang farmasi, 4 perusahaan yang bergerak di industri rokok, 4 perusahaan bergerak di industri kosmetik, dan 3 perusahaan bergerak di peralatan rumah tangga.

Adapun data yang digunakan adalah data sekunder. Data sekunder merupakan data yang diperoleh lewat pihak lain, tidak secara langsung dari subyek penelitian (Azwar, 2013). Pengambilan data dilakukan dengan mengamati dan mencatat nilai yang terkait dengan kinerja keuangan perusahaan dari tahun 2010-2013 melalui faktor-faktor; ratio inventory turnover, Weeks of Supply, net profit margin, gross profit margin, operating margin, pretax margin, cash flow to liabilities, cash flow to sales revenue dan cash flow to total assets sebelum implementasi ERP dan sesudahnya. kemudian peneliti mengambil data perusahaan tersebut dengan melakukan komunikasi dengan pihak perusahaan untuk mengetahui kapan perusahaan melakukan launching ERP. Komunikasi yang dilakukan dengan perusahaan dengan metode judgmental sampling dengan tujuan mereka yang memberikan informasi kepada peneliti merupakan orang yang tepat dan memahami kondisi perusahaan sebagai obyek peneliti, selain itu peneliti melakukan penelusuran lewat internet untuk validasi data.

Menguji apakah penggunaan sistem ERP berdampak pada kinerja keuangan perusahaan, maka peneliti akan melakukan uji beda antara sebelum launching ERP dibandingkan dengan sesudah launching ERP dengan melakukan pengujian paired t-test dengan bantuan software SPSS. Apabila nilai $p$ value lebih besar dari nilai signifikan, berarti pvalue tidak signifikan, itu berarti kita harus menerima $\mathrm{H}_{0}$ dan menolak $\mathrm{H}_{1}$ atau dengan kata lain bahwa tidak ada perbedaan sebelum dan sesudah launching ERP. Penelitian yang dilakukan, dengan hipotesis yang akan dibuktikan oleh peneliti tidak terbukti atau tidak dapat diterima. Dan jika nilai pvalue lebih kecil atau sama dengan nilai signifikan, berarti pvalue signifikan, itu 
berarti kita harus menolak $\mathrm{H}_{0}$ dan menerima $\mathrm{H}_{1}$. Penelitian yang dilakukan, dengan hipotesis yang akan dibuktikan oleh peneliti telah terbukti atau dapat diterima.

\section{HASIL DAN PEMBAHASAN}

Analisa lebih lanjut dilakukan terhadap 33 perusahaan consumer good dan dua perusahaan tidak dapat diolah lebih lanjut disebabkan perusahaan tersebut sudah melaunching ERP sebelum masuk bursa saham. Berdasarkan hasil pengumpulan dan pengolahan data maka dapat terlihat pada Tabel 2. Pengujian hipotesis pada penelitian dilakukan dengan membandingkan nilai kuartil pertama, kedua dan ketiga antara sebelum dan sesudah launching ERP terhadap kinerja keuangan perusahaan.

Tabel 2

Rekap Nilai Perhitungan SPSS Indikator Kinerja Perusahaan

\begin{tabular}{|r|l|r|r|r|}
\hline \multirow{2}{*}{ No } & \multirow{2}{*}{ Indikator } & \multicolumn{2}{|c|}{ Nilai Mean } & \multirow{2}{*}{ Nilai Sig } \\
\cline { 3 - 5 } & & sebelum ERP & sesudah ERP & \\
\hline 1 & Inventory Turnover & -162.729 .997 & 4.471 .694 & .014 \\
\hline 2 & Weeks of Supply & 11.789 .452 & 12.448 .767 & .000 \\
\hline 3 & Net Profit Margin & -.021088 & .035939 & .011 \\
\hline 4 & Gross Profit Margin & .273788 & .303882 & .000 \\
\hline 5 & Operating Margin & .052427 & .080121 & .000 \\
\hline 6 & Pretax margin & .010082 & .043542 & .000 \\
\hline 7 & Cash flow to Liabilities & .218742 & .353515 & .317 \\
\hline 8 & Cash flow to Sales revenue & .000739 & .039948 & .190 \\
\hline 9 & Cash flow to total assets & .096503 & .079518 & .001 \\
\hline
\end{tabular}

Berdasarkan hasil perhitungan dan penggunaan SPSS version 13.00 didapatkan hasil uji beda rata-rata inventori turnover ratio yakni terdapat nilai signifikansi 0.014 . Dimana nilai $0.014 \leq$ nilai signifikan $(0.05)$, berarti harus menolak $\mathrm{H}_{0}$ dan menerima $\mathrm{H}_{1}$. Dengan kata lain, hipotesis dapat diterima, bahwa terdapat perbedaan yang signifikan antara sebelum dan sesudah launching ERP dari rata-rata faktor inventori turnover ratio. Dimana terjadi peningkatan sehingga memberikan efektifitas dan efisiensi bagi perusahaan.

Apabila dilihat dari sisi weeks of supply yang mengindikasikan proses yang lebih efisien pada bagian operasional perusahaan setelah launching ERP hal ini terlihat pada rata-ratanya yang lebih besar, ditelaah lebih lanjut dari week of supply terjadi peningkatan setelah launching ERP mengindikasikan bahwa perusahaan mengalami ketidakefektifan hubungan dengan supplier, hal ini disebabkan supplier masih belajar untuk memahami sistem pada perusahaan yang telah terjadi integrasi data sehingga weeks of supply meningkat.

Analisa dari faktor net profit margin dapat dilihat nilai signifikansi 0.011 . Dimana nilai $0.011 \leq$ nilai signifikan $(0.05)$, berarti harus menolak $\mathrm{H}_{0}$ dan 
menerima $\mathrm{H}_{1}$. Dengan kata lain, hipotesis terbukti atau dapat diterima, bahwa terdapat perbedaan yang signifikan antara sebelum dan sesudah launching ERP dari rata-rata faktor net profit margin. Dimana rata-rata net profit margin sebelum implementasi sebesar -,021 menjadi 0,359; hal ini mengindikasikan terjadinya peningkatan profit bagi perusahaan yang memberikan peningkatan daya saing.

Sedangkan berdasarkan hasil test gross profit margin didapatkan nilai signifikansi 0.000 . Dimana nilai $0.000 \leq$ nilai signifikan $(0.05)$, berarti harus menolak $\mathrm{H}_{0}$ dan menerima $\mathrm{H}_{1}$. Dengan kata lain, hipotesis terbukti atau dapat diterima, bahwa terdapat perbedaan yang signifikan antara sebelum dan sesudah launching ERP dari rata-rata faktor gross profit margin. Dimana rata-rata gross profit margin sebelum implementasi sebesar 0,274 menjadi 0,304; hal ini mengindikasikan terjadinya peningkatan profit bagi perusahaan yang memberikan peningkatan daya saing.

Berdasarkan hasil test operating margin didapatkan nilai signifikansi 0.000 . Dimana nilai $0.000 \leq$ nilai signifikan $(0.05)$, berarti harus menolak H0 dan menerima H1. Dengan kata lain, hipotesis terbukti atau dapat diterima, bahwa terdapat perbedaan yang signifikan antara sebelum dan sesudah launching ERP dari rata-rata faktor operating margin. Dimana rata-rata operating margin sebelum implementasi sebesar 0,0524 menjadi 0,0801 ; hal ini mengindikasikan terjadinya peningkatan operating margin bagi perusahaan sehingga memberikan peningkatan daya saing.

Berdasarkan hasil test terhadap pretax margin didapatkan nilai signifikansi 0.000 . Dimana nilai $0.000 \leq$ nilai signifikan $(0.05)$, berarti harus menolak $\mathrm{H} 0$ dan menerima H1. Dengan kata lain, hipotesis terbukti atau dapat diterima, bahwa terdapat perbedaan yang signifikan antara sebelum dan sesudah launching ERP dari rata-rata faktor pretax margin. Dimana rata-rata pretax margin sebelum implementasi sebesar 0,101 menjadi 0,435; hal ini mengindikasikan terjadinya peningkatan pretax margin bagi perusahaan sehingga memberikan peningkatan daya saing.

Apabila ditelaah dari faktor cash flow ratio dengan tiga indikasi yakni: cash flow to liabilities, cash flow to sales revenue dan cash flow to total assets.

1. $\mathrm{H}_{0}: \mu_{1}=\mu_{2}$. Bahwa tidak terdapat perbedaan yang signifikan antara sebelum dan sesudah launching ERP dari rata-rata faktor cash flow to liabilities.

2. $\mathrm{H}_{7}: \mu_{1} \neq \mu_{2}$. Terdapat perbedaan yang signifikan antara sebelum dan sesudah launching ERP dari rata-rata faktor cash flow to liabilities.

3. $\mathrm{H}_{0}: \mu_{1}=\mu_{2}$. Bahwa tidak terdapat perbedaan yang signifikan antara sebelum dan sesudah launching ERP dari rata-rata faktor cash flow to sales revenue.

4. $\mathrm{H}_{8}: \mu_{1} \neq \mu_{2}$. Terdapat perbedaan yang signifikan antara sebelum dan sesudah launching ERP dari rata-rata faktor cash flow to sales revenue.

5. $\mathrm{H}_{0}: \mu_{1}=\mu_{2}$. Bahwa tidak terdapat perbedaan yang signifikan antara sebelum dan sesudah launching ERP dari rata-rata faktor cash flow to total assets.

6. $H_{9}: \mu_{1} \neq \mu_{2}$. Terdapat perbedaan yang signifikan antara sebelum dan sesudah launching ERP dari rata-rata faktor cash flow to total assets.

Hasil ketiga hipotesis tersebut terdapat pada tabel 2. Berdasarkan hasil tabel tersebut didapatkan bahwa cash flow total assets yang memiliki nilai signifikan 
yakni $0,001 \leq 0,05$. Berdasarkan hasil test terhadap cash flow ratio didapatkan bahwa CFO CFOto liabilities dan CFO to sales revenue tidak siginifikan. Hal ini berarti tidak terdapat perbedaan antara sebelum dan sesudah launching ERP. Sedangkan CFO to total assets memiliki tingkat signifikansi, sehingga nilai 0.001 $\leq$ nilai signifikan (0.05), berarti harus menolak $\mathrm{H}_{0}$ dan menerima $\mathrm{H}_{1}$. Dengan kata lain, hipotesis terbukti atau dapat diterima, bahwa terdapat perbedaan yang signifikan antara sebelum dan sesudah launching ERP dari rata-rata faktor pretax margin. Dimana rata-rata $C F O$ to total assets sebelum launching sebesar 0,965 menjadi 0,795; hal ini mengindikasikan terjadinya penurunan $C F O$ to total assets bagi perusahaan.

Hasil penelitian di atas sesuai dan cukup signifikan dengan beberapa hasil penelitian yang dilakukan antara lain oleh Yusuf, et al., (2006) yang menyatakan bahwa ERP merupakan fungsi sistem aplikasi software yang dapat membantu organisasi dalam mengendalikan bisnis yang lebih baik karena dapat mengurangi tingkat stok dan inventori, meningkatkan perputaran stok, mengurangi cycle time order, meningkatkan produktivitas, komunikasi lebih baik serta berdampak pada peningkatan benefit (profit) perusahaan. Kemudian Leon (2005) yang menyatakan bahwa ERP mempunyai keuntungan dengan pengurangan lead-time, pengiriman tepat waktu, pengurangan dalam waktu siklus, kepuasan pelanggan yang lebih baik, kinerja pemasok yang lebih baik, peningkatan fleksibilitas, pengurangan dalam biaya-biaya kualitas, penggunaan sumber daya yang lebih baik, peningkatan akurasi informasi dan kemampuan pembuatan keputusan. Adapun Herdiawan dalam Warta Ekonomi (2006) menyatakan bahwa sistem ERP telah diterapkan pada perusahaan manufaktur makanan yang mendapatkan keuntungan yakni integrasi sistem di seluruh grup perusahaan; data informasi menjadi lebih lengkap, detail dan cepat; memudahkan direksi membuat analisis dan mengambil keputusan; proses usaha yang lebih sederhana; penghematan ongkos produksi; dan terakhir arus kas perusahaan yang lebih terkontrol.

\section{E. SIMPULAN}

Berdasarkan analisa data yang dilakukan pada 33 perusahaan consumer good yang terdaftar pada bursa efek Indonesia dengan membandingkan sebelum dan sesudah launching ERP terhadap indeks fianancial performance yang ditelaah dari indikator turnover inventory ratio, weeks of supply, net profit margin, gross profit margin, operating margin and pretax margin dan cash flow ratio dapat disimpulkan bahwa terdapat perbedaan yang signifikan antara kinerja keuangan perusahaan sebelum dan sesudah launching ERP. Kinerja keuangan perusahaan meningkat setelah menggunakan ERP. Hal ini mengindikasikan adanya efektifitas dan efisiensi perusahaan dalam mengelola sumberdaya keuangan setelah menggunakan ERP. Dengan demikian hasil ini diharapkan mampu meningkatkan daya saing perusahaan di masa yang akan datang. 


\section{DAFTAR PUSTAKA}

Azwar, Saifuddin. (2013). Metode Penelitian. Yogyakarta: Pustaka Pelajar.

Aladwani, A.M. (2001). "Change Management Strategies For Succsessful ERP Implementation”. Business Process Management Journal, Vol.7 no.3 pp. 266-275.

Baheshti, H.M. (2006) "What Manager Should Know About ERP/ERP II". Management Research New Vol.29 No.4, pp. 184-193.

Bradford, M., and Florin, J. (2003). "Examining the Role of Innovation Diffusion Factors on the Implementation Success of Enterprise Resources Planning Systems". International Journal of Accounting Information System $4 \mathrm{pp}$. $205-225$.

Genoulaz, V.B., and Millet, P.A. (2006). "An Investigation into the Use of ERP System in the Service Sector". International Journal of Production Economics 99 pp.202-221.

Gupta, A. (2000). "Enterprise Resources Planning: The Emerging Organizational Value System". Industrial Management and Data System Journal Vol.100 No.3, pp.114-118.

Herdiawan, P. (2006). " Laporan Penerapan ERP pada Perusahaan PT. Zyrexindo Mandiri Buana". Warta Ekonomi , 23 Juni 2006, wartaekonomi.com.

Hong, K., and Kim, Y. (2002). "The Critical Success Factor for ERP Implementation: An Organizational Fit Perspective". Information and Management 40, pp. 25-40.

Kumar, V., Maheshwari, B., Kumar, U. (2003). "ERP System Implementation: Best Practices in Government Organizations". Government Information Quarterly 19 pp 147-172.

Lakonishok I, Vermaelen J. (1995). "Market Under reaction to open market share repurchases". Journal Finance Econ Vol. 39 No.2/3 pp.81-209.

Leon, A. (2005). "Enterprise Resources Planning". McGraw-Hill Publishing Company Limited: New Delhi.

Mabert, V.A., Soni, A, Venkataramanan, M.A. (2001). "Enterprise Resources Planning: Common Myths Versus Evolving Reality". Business Horizon/ May-June.

Nah, F., Lau, J., and Kuang. (2001). "Critical Factor For Successful Implementation of Enterprise System". Business Process Management Journal Vol.7 No.3, pp. 285-297.

Sabana, A. (2002). “Enterprise Resources Planning di PT Ultrajaya Milk Industry \& Trading Tbk" Warta Ekonomi. 
Spathis, C., and Constantinides, S. (2003). "The Usefulness of ERP System for effective Management". Industrial Management and Data System Journal, Vol.103 No.9 pp.677-685.

Soja, P. (2006). "Succsess Factor in ERP Implementation: Lesson From Practice”. Journal of Enterprise Information Management Vol.19 No.6 pp.646-661.

Sugiyono. (2015). Metode Penelitian Kuantitatif Kualitatif dan R\&D. Bandung : Alfabeta.

Sugiyono. (2015). Statistika untuk Penelitian. Bandung : Alfabeta.

Sukardi. (2009). Metodologi Penelitian Pendidikan. Jakarta: PT.Bumi Aksara.

Sun, A.Y.T., Yazdani, A., Overend, J.D. (2005). "Achievement Assessment for Enterprise Resources Planning (ERP) System Implementation Based on Critical Success Factors (CFS)". International Journal Production Economics 98 pp. 189-203.

Umble, E.J., Haft, R.R., Umble, M.M. (2003). "Enterprise Resources Planning: Implementation Procedures and Critical Success Factors”, Europen Journal of Operation Research 146 pp. 241-257.

Warta Ekonomi. (2002). Warta Ekonomi 6 Juni 2002, wartaekonomi.com.

Wier, B., Hunston, J., HassabElnaby, H.R. (2007). "Enterprise Resources Planning System and non-Financial Performance Incentives: The Joint Impact on Corporate Performance". International Journal of Accounting Information System Vol.8 pp.165-190.

Wu, J.H., Wang, Y. M. (2007). "Measuring ERP success: The key-users "Viewpoint of the ERP to Produce a Viable IS in the Organization". Computer in Human Behavior 23 pp. 1582 - 1596.

Yusuf, Y., et al. (2006). "Implementation of Enterprise Resources Planning in China". International Journal Production Economics.

Zang, Z., Lee, M.K.O., Huang, P., Zhang, L., Huang, X. (2005). “A framework of ERP systems implementation success in China: An empirical study". International Journal Production Economics 98 pp. 56-80. 